\title{
The entangled bank unravels
}

\section{「生物多様性年」を迎えて}

Nature Vol. 462(251-252)/19 November 2009

「多くの種類の数多くの植物が地表を覆い、鳥が灌木に止 まってさえずり、さまざまな昆虫が飛び回り、湿った地中 をミミズがはいまわる。このように種のもつれ合った土手 を思い浮かべるのはおもしろい」チャールズ・ダーウィ ンの『種の起源』の最終段落はこう始まるが、2009 年 11 月 24 日、この本が出版 150 周年を迎えた。ダーウィンは、 こうした穏やかなイメージを使い、自然選択の過程を通じ て、極めて美しく極めてすばらしい生物種（すべて）が、 際限なく進化してきたことを強調しようとした。

しかし、もし彼が今日生きていれば、これほどの高揚感 はもたないだろう。土手では、森林伐採によって在来植物 種がほとんど失われ、侵入低木で占められるようになり、 近くを流孔る河川は污染され、過剩な表面流出による堆積 物がたまっているからだ。ダーウィンにインスピレーショ ンを与えた生物の隆盛が、今では大きく損なわれているこ とは旧聞に属する。11月、国際自然保護連合(IUCN)がレッ ドリスト（絶滅の抢それがある動植物のリスト）に発表し たデータによれば、哺乳類の $1 / 5$ と両生類の約 $1 / 3$ が絶 滅の危機にさらされている。植物も同様で、針葉樹など既 知の裸子植物の約 $1 / 3$ が絶滅の危機に瀕している。

科学者や環境保護論者があれほど警告したにもかかわ らず、各国政府がしたのは、この問題を心配することく らいだった。世界の約 200 か国は、生物多様性条約の締 約国となり、生物多様性の減少率を 2010 年までに大き く減らすことを約束していた。ところが指導者たちは、 目標が達成されないことを予想しており、そもそもこの 目標が基本的に達成不可能なもので、むしろ政治声明と しての意味合いが強かったことを認めている (Nature 2009 年 11 月 19 日号 263 ページ参照)。

この 1 年、Nature はダーウィンの功績をたたえる特集 を組んできたが (www.nature.com/darwin)、11月 19 日号はその最後として、生物多様性の減少に関する緊急
課題と問題解決への取り組みについて取り上げた。各国 政府上層部は、ようやく生物多様性の危機に注目し始め たようだ。例えば国連総会では、2010 年を「国際生物多 様性年」とすることが決議され、来る 9 月には、米国ニュー ヨークの会議で各国元首がこの問題を取り上げる予定に なっている。10月には生物多様性条約の締約国が名古屋 市に集まり、今後数十年間にわたる各国の具体的かつ検 証可能な生物多様性の目標を策定する。各国は今後 11 か 月間に極めて重要な生態系の保護に着手し、成果を名古 屋での首脳会議で発表しょうという意欲を高めている。

「生態系サービス」という概念、すなわち、多様な生 態系によって大きな経済効果が得られることが徐々に認 知されてきており、産業界や政界での環境保全に対する 支援が強化されている。「生態系と生物多様性の経済学 (TEEB)」という国際研究プロジェクトのリーダーは、政 府は、自然の「公共財」を保護するための税制や給付金 制度を定める必要がある、と主張している。

今日、生物多様性に対する最大の脅威は、生息地の急 激な消失だ。現在では、全世界の陸地表面のわずか約 $14 \%$ と領海の $6 \%$ 足らずが保護されているにすぎない。 それでも、こうした保護区域が世界人口のほぼ $1 / 6$ を支 えるうえで役立っていることが TEEB の研究で明らかに なっている。2010 年までの目標を達成できない見通しが 強まり、各国は次なる行動を考えている。なかでも、最 も絶滅の危機に瀕した生物種の貴重な保護生息地を選定 することは、極めて重要なテーマとなるだろう。

社会の最富裕層は、自然から最も離孔たところで生活 し、最貧層は、多様な生態系の果実に大きく依存する傾 向がある。したがって、環境保全政策の策定にあたつては、 人間、特に保護区域の設定によって間接的に被害を受ける 現地のコミュニティーが絶対に犠牲にならないように配慮 しなければならない。（菊川要 訳） 